\title{
Influence of Adult Literacy Education on the Environmental Behaviours of Women
}

\author{
Erhabor Igbinosa Norris M.Sc \\ Osayande E.I. PhD \\ Department of Health Safety and Environmental Education \\ University of Benin.
}

doi: 10.19044/esj.2017.v13n20p241 URL:http://dx.doi.org/10.19044/esj.2017.v13n20p241

\begin{abstract}
The study assessed the influence of adult literacy education on the environmental attitudes and behaviours of women in Edo State. A sample size of 253 respondents were selected using both census sampling to select the 15 adult literacy centers in the state and simple random sampling by balloting to choose the sample for the study. The instrument for the study had a reliability of 0.75 for the attitude subscale and 0.83 for the behaviours subscale. It was observed from the study that the majority of the respondents (57.3\%) had a positive attitude towards the environment and their response revealed that they rarely partake in most pro-environmental behaviours. There was a weak positive relationship observed between the respondents' environmental attitude and their environmental behaviour. Hence the researchers recommended that more emphasis should be placed on implementing adult environmental education in each of the adult literacy centers in Edo State.
\end{abstract}

Keywords: Environmental behaviour; Environmental attitude; adult education

\section{Introduction}

Environmental degradation in Nigeria can be attributed to the reckless use of its rich natural resources as a result of poverty, population growth, illiteracy, greed, corruption, ignorance amongst others. Some of the manifestation of this rate of degradation in the society includes problems emanating from improper waste disposal, urban decay, erosion, flooding, prevalence of pest and diseases, desertification, deforestation, drought, conflict and others. Thus these various environmental problems pose negative impact on the health and wellbeing of the human populace and other living organisms in the society. However, for the purpose of this study, 
the health, social and psychological impact on women would be of great priority. Women are said to be the hardest hit by the various negative aftermath of environmental degradation (natural disasters) because they are considered as more vulnerable than their male counterpart in the society. Also their physiological make up which is more fragile than those of males, is one of the reasons attributed for women being considered as a vulnerable group to the aftermath of environmental disasters or issues. Hence they tend to be more susceptible to the hazardous effects of environmental pollution especially through the use of persistent organic pollutant. These pollutants can enter women fragile body tissues and breastmilk through which they pass onto infants, causing reproductive and immunological disorders (Ndaruzaniye, 2013).

Although United Nations Environmental Program UNEP (2010) asserted that women are not just vulnerable because they are naturally weaker but their vulnerability can be explained because the conditions in the environment faced by men and women are different due to their gender. Like in developing countries, women especially the rural women form the largest group of the world poorest and most vulnerable people due to their outstanding duty as primary providers of food, water, fuel for their families thereby making them susceptible to the harsh reality of climate change and other environmental crisis. Thus their livelihood are negatively affected as their income, food source, water and so on are usually lost. Also their male counterpart contribute to the women woes in the environment as they cut down trees and pollute nearby water source without replacing the trees and finding solutions to the polluted water or locate alternate for their women to harvest from. These scenarios increases the time women spend searching for wood fuel and harvesting water instead of engaging in other more profitable activities in the society.

Consequently, other reasons women are seen as vulnerable to the negative consequences of environmental degradation are that they tend to have limited access to physical, financial, human, social and natural capital or assets; lack of opportunity to have or possess adequate knowledge and awareness on environmental issues; climate change tend to affect the education of the girl child especially due to the fact that they are more likely to drop out of school and help out in the family (Ndaruzaniye, 2013). They are more susceptible to indoors air pollutants as they spend more time their cooking, cleaning and generally taking care of the family thereby making them exposed to the various pollutants found in the indoor environment.

Meanwhile, women are not only seen as victims of environmental degradation but also have a pertinent role to play in building active responses to direct environmental issues faced in the society. Accordingly, some of the pivotal roles women engage in protecting and conserving the environment 
starts from the home scene. As Okukpon (2008) highlighted, women are the hub of the home in both rural and urban communities as they cater and meet up the environmental condition of members of the household even if it involves ignoring their own need. They are responsible for the disposal of waste in the household and other pro-environmental behaviours. Thus lack of knowledge and awareness on how to manage this waste appropriately will lead to inadequate waste disposal. This can result in increased risk of water and air borne diseases. Therefore this raises the need for education and capacity building of women in matters that relate to environmental degradation.

In Nigeria context, although women are still marginalized as they are considered less effective or important contributors to economic gain and development; legislative process or solutions to environmental problems. But it has been observed in recent time that there are women with expertise in the areas of environmental sustainability, protection and conservation particularly in the academic and institutions of higher learning. They are usually few and sometimes not given the chance to work effectively in the field. In this regard, based on the recognition by the government of the importance of women in decision making at all levels especially on environmental issues and the need for integrating gender into policy formulation, the Nigeria government has made several attempt to create space for women experts and involve them in policy making. But it has been noticed in the various parliamentary and judicial arm of government that their numbers are significantly low for their impact to be felt fully.

Accordingly, this raises the need for a national awareness program on environmental issues in order to provide women with appropriate knowledge, attitude, skills, effective participation to resolve, cope, mitigate and adapt to the various environmental challenges faced in the society. Therefore this brings to the fore environmental education in actualizing the increased environmental literate citizens in the country. However, environmental education is a means of producing a wholesome educational experience in which schools and communities interact together to produce an influencing effect on the environmental literacy of the society. However, adult females are of priority for this study. Therefore adult education is pertinent in actualizing the goal of an increase in environmental literacy citizens in the country especially among the females who lacked the opportunity of attending a formal education in their early years of life. Adult literacy education is very important in a developing society and this statement is corroborated by President Julius Nyerere (former Tanzania president) when he stated that the younger generation will not have an impact on our economic development for five, ten or even twenty years and thus, the attitude of adults now has more impact now. Therefore, this raised 
the need for adult education for women on environmental issues. And the branch of adult education which emphasis environmental issues or environmental education is known as Environmental Adult Education (EAE). EAE combines environmental education and adult learning theory to provide meaningful educative experiences to learners with the purpose of bringing about genuine environmental change. EAE is a major component of adult education curriculum and it is focused on changing the environmental behavior of individuals in order to stop environmental degradation in the country through providing learners with adequate skills, knowledge, attitude and enable them partake in resolving environmental issues in the society.

Therefore it is worthy of note that several studies has been carried out to indicate the impact of education on environmental knowledge and behavior of individuals. Research by Kaplowitz and Levin (2005) and Kentucky Environmental Education Council (2009) revealed that higher level of education results in higher education knowledge. Also the work of Hungerford and Tompera (1987) showed evidence of a weak positive relationship between educational level and environmental behaviours, also a weak positive relationship between attitudes and environmental behaviours. However for this present study, it involves investigating the extent in which EAE has influenced the environmental attitudes and environmental behaviours of women who are seen as the most vulnerable and have a pivotal role to play in curbing environmental problems in the society. Also measures on the women level of awareness and attitude towards the environment will also be carried out by the researchers in this study.

\section{Purpose of the study}

This study is embarked upon to ascertain the influence of adult literacy education the environmental behavior of women in Nigeria. The vulnerability towards the aftermath of various environmental crises, role of women in curbing these environmental crisis from causing serious harm in the society and the need to increase the environmental literacy of women and their society motivated the researcher in embarking on this study.

\section{Research questions}

The following research questions are proposed for this study:

1. What are the attitudes of women towards the environment?

2. What is the environmental behavior of the women?

\section{Methodology}

The study focused on the women in the various adult literacy centers in Edo State. The fifteen (15) registered adult literacy centers were selected in Edo State. Thus a total of 2530 female adult education students made up 
the population of the study. (Edo State Ministry of Education, 2016). A census and a simple random sampling techniques were used to select $10 \%$ of the population for the study. Census sampling technique was used to select all fifteen (15) adult literacy centers in Edo State then simple random sampling technique by balloting was used to select 253 respondents for the study.

The Kaiser, Ranney, Hartig and Bowler (1999) General Ecological Behavior (GEB) scale was adapted to assess the environmental behavior, attitude and behavior. The GEB measure Rasch scale based on a dichotomous model within item responsibility. In this study, GEB consist of 28 items which was adapted to suit the Nigerian context. The items represent different types of ecological behavior and some non- environmental prosocial behavior. This scale is used based on the assumption that environmental knowledge, environmental values and responsible feelings (components of the questionnaire), predicts ecological behavior. The items were modified into a 4 point likert scale (1- strongly disagree, 2- disagree, 3agree, 4- strongly agree). Although negatively formulated items were reversed in the coding. The instrument used for this study was given to three experts in this field of study. Two of the experts were chosen from the Department of Health, Safety and Environmental Education and one expert from the Department of Adult and Non Formal Education in the University of Benin. The reliability of each subscale for the survey was done by the researcher to determine the internal consistency of the questionnaire. For the attitude subscale, the coefficient alpha equals 0.75. While for the behaviour subscale coefficient alpha equals 0.89 . The numbers indicate that each section is reliable.

For the data analysis, the statistical package for the social sciences (SPSS version 20) was the computer software used to analyse the collected data. And the statistical analsysis that was applied for the study are the descriptive statistics of frequency count and percentage. The Pearson Moment Correlation was used to assess the relationship between the two variables.

\section{Result}

Research question one: What are the attitudes of the women towards the environment?

Table one: Attitude of the respondents towards the environment.

\begin{tabular}{|l|l|l|}
\hline Attitude & Frequency & Percentage \\
\hline Positive & 145 & 57.3 \\
\hline Negative & 108 & 42.7 \\
\hline Total & 253 & 100 \\
\hline
\end{tabular}


The table above reveals the attitude of the respondents towards the environment. The table shows that $57.3 \%$ of the respondents have a positive attitude towards the environment while $42.7 \%$ have a negative attitude towards the environment. This shows that most of the respondents have a positive attitude towards the environment.

Research question two: What are the behaviours of the respondents towards the environment?

Table two: Behaviours of the respondents towards the environment.

\begin{tabular}{|l|l|l|l|l|l|l|l|l|l|}
\hline s/n & Items & \multicolumn{2}{l}{$\begin{array}{l}\text { Very } \\
\text { Frequent }\end{array}$} & \multicolumn{2}{l|}{ Frequent } & \multicolumn{2}{l|}{ Rarely } & \multicolumn{2}{l|}{ Not at all } \\
\cline { 3 - 10 } & & F & $\%$ & F & $\%$ & F & $\%$ & F & $\%$ \\
\hline 1 & $\begin{array}{l}\text { I encourage the planting } \\
\text { trees in my surrounding }\end{array}$ & 82 & 33.4 & 106 & 41.9 & 27 & 10.7 & 38 & 15.0 \\
\hline 2 & $\begin{array}{l}\text { I give talk in the school } \\
\text { about climate change } \\
\text { adaptation strategies }\end{array}$ & 22 & 8.7 & 44 & 17.4 & 103 & 40.7 & 84 & 33.2 \\
\hline 3 & $\begin{array}{l}\text { I have internal discussion } \\
\text { with friends and family } \\
\text { on climate change }\end{array}$ & 99 & 39.1 & 73 & 28.9 & 65 & 25.7 & 16 & 6.3 \\
\hline 4 & $\begin{array}{l}\text { I install rain water tanks } \\
\text { in my house in time of } \\
\text { rain }\end{array}$ & 94 & 37.2 & 94 & 37.2 & 56 & 22.1 & 9 & 3.6 \\
\hline 5 & $\begin{array}{l}\text { I encourage child led } \\
\text { climate change response } \\
\text { activities }\end{array}$ & 82 & 32.4 & 71 & 28.1 & 92 & 36.4 & 8 & 3.2 \\
\hline 6 & $\begin{array}{l}\text { I look after trees in my } \\
\text { surrounding }\end{array}$ & 76 & 30.0 & 71 & 28.1 & 85 & 33.6 & 21 & 8.3 \\
\hline 7 & $\begin{array}{l}\text { I throw pure water sachet } \\
\text { anywhere in the } \\
\text { environment }\end{array}$ & 83 & 32.8 & 73 & 28.9 & 68 & 26.9 & 29 & 11.5 \\
\hline 8 & $\begin{array}{l}\text { I have written to the } \\
\text { government to express } \\
\text { my opinion on } \\
\text { environmental problems }\end{array}$ & 65 & 25.7 & 31 & 12.3 & 86 & 34.0 & 71 & 28.1 \\
\hline 9 & $\begin{array}{l}\text { I voted for a politician } \\
\text { due to his/ her record on } \\
\text { protection of the } \\
\text { environment }\end{array}$ & 78 & 30.8 & 95 & 37.5 & 60 & 23.7 & 20 & 7.9 \\
\hline 10 & $\begin{array}{l}\text { I reported environmental } \\
\text { crimes to the appropriate } \\
\text { authorities }\end{array}$ & 68 & 26.9 & 50 & 19.8 & 75 & 29.6 & 60 & 23.7 \\
\hline
\end{tabular}

The table reveals the behaviours of the respondents towards the environment. it shows whether they engage in either anti-environmental behaviour or pro-environmental behaviour from the table. It can be deduced that $41.9 \%$ of the respondents frequently encourage the planting of trees in their surrounding. Most of the respondents stated that they rarely (40.7\%) 
give climate change talk in the school. However, 39.1\% stated that they very frequently have internal discussion with friends and family on climate change. From the table, it can also be deduced that $37.2 \%$ frequently install rain water tanks in their houses in time of rain while $36.4 \%$ reportedly stated that they rarely encourage child led climate change response activities. However $33.6 \%$ stated that they rarely look after trees in their surrounding and $32.8 \%$ very frequently throw pure water sachet anywhere in their surrounding. Most of the respondents stated that they have rarely written to the government to express their opinion on environmental problems. Although $37.5 \%$ stated that they voted for a politician due to his or her record on protection of the environment. But most of them stated that they rarely report environmental crimes to the appropriate authorities. It can therefore be inferred from the table that most of the respondents rarely partake in pro-environmental behaviour towards the environment based on the items in the questionnaire.

Research question three: What is the relationship between attitudes and behaviours of the respondents to the environment?

Table three: Pearson Correlation for the relationship between attitudes and behaviours of the respondents to the environment.

\section{Correlations}

\begin{tabular}{|ll|r|r|}
\hline & & \multicolumn{1}{|c|}{ attitude } & \multicolumn{1}{c|}{ behaviour } \\
\hline \multirow{4}{*}{ attitude } & Pearson Correlation & 1 & $.270^{* *}$ \\
& Sig. (2-tailed) & & .000 \\
& $\mathrm{~N}$ & 253 & 253 \\
& Pearson Correlation & $.270^{* *}$ & 1 \\
behaviour & Sig. (2-tailed) & .000 & \\
& $\mathrm{~N}$ & 253 & 253 \\
\hline
\end{tabular}

The table three reveals the relationship between attitude and behaviour of the respondents towards the environment. It can be deduced that there is a positive weak relationship between attitude and behaviour of the respondents towards the environment $(r=0.270, \mathrm{p}=0.000)$. This shows that the relationship is significant.

\section{Discussion of findings}

This study was embarked upon to assess the influence of adult literacy on women attitude and behaviour towards the environment. From the data collected from the respondents, it can be deduced that majority of the respondents possess positive, pro-environmental or environmentally friendly attitude toward the environment. That is $57.3 \%$ had positive attitude while $42.7 \%$ had negative attitude towards the environment. This is substantiated by the work of Caldwell (2011) when he revealed that respondents in 
Ontario, Canada showed concern about the local environmental issues. Also Eilam and Trop (2010) also revealed that respondents possess positive attitude towards the environment but the strategies required for influencing attitude are different from those required for influencing attitudes are different from those required for influencing behaviours.

However, with regard to the behaviours of the respondents towards the environment, the study revealed that the respondents rarely partake in pro-environmental behaviours. This can be deduced in table two where majority of the respondents stated that they rarely give talk in school on climate change adaptation strategies, encourage child led climate change response activities, look after trees in the surrounding, write to the government to express their opinion on environmental problems and reported environmental crimes to the appropriate authorities. This is in line with the study by Digby (2010) when he reported that the response of his participants in the study showed that proenvironmental behaviour which was mixed with some reporting environmentally friendly behaviour while others did not. Digby study was done among adults in Minnesota.

Furthermore, a Pearson Correlation was conducted to ascertain the relationship between attitude and behaviour of the respondents towards the environment. This study revealed a weak positive relationship between attitude towards the environment and their environmental behaviour. This is in contrary with the work of Hines, Hungerford and Tomera (1987) and Digby (2010) when they revealed in their various studies a moderate positive relationship between attitude towards the environment and environment behaviour. Meanwhile the result from the research is inline with Coyle (2005) when his study showed a positive weak relationship between increased knowledge and a positive attitude and behaviour change.

\section{Conclusion}

Women are not only seen as the group who receive the brunt of the burden of environmental disasters but also their activities have an impact on natural resources and the environment especially in sub-Saharan Africa. That is Africa women are not only victims of natural resource depletion but also on pollution in which they have a major role in its production. This brings the need to promote and develop environmentally friendly behaviours among women. It can be inferred from the findings of the study that adult literacy education has a minimal influence on the environmental attitudes and behaviours of women towards the environment. This reveals that more need to be done to promote proenvironmental behaviours among women in Nigeria especially through raising their awareness and knowledge. 


\section{Recommendation}

The following recommendations were proposed by the researchers. They include

1. Environmental programmes should be proposed or established that will enable equal response to the different impacts climate change has on men and women

2. There should be full participation of women in decision making using gender response environmental planning and management as a contributing factor to resolving environmental disasters.

3. Training in the management of natural resources and the environment should be emphasized in the adult literacy centers.

4. Training on the control of women health as well as being able to sustain natural resources should be taught in adult literacy centers.

\section{References:}

1. Cardwell F (2011). Knowledge, attitudes and practices of global environmental change and health: toward sustainable behaviour change?. A Thesis Submitted to the School of Graduate Studies In Partial Fulfillment of the Requirements. McMaster University

2. Coyle, K. (2005). Environmental literacy in America: What ten years of NEETF/Roper research and related studies say about environmental literacy in the U.S. The National Environmental Education \& Training Foundation. Retrieved May 6, 2006 from http://www.neetf.org/pubs/ELR2005.pdf

3. Digby, C.L. (2010). An Examination of the Impact of Non-formal and Informal Learning on Adult Environmental Knowledge, Attitudes, and Behaviors. EdD Dissertation, Unpublished. Minnesota. The University Of Minnesota.

4. Eilam, E. \& Trop, T. (2010). Environmental attitudes and environmental behavior-which is the horse and which is the cart. Sustainability 4, 2210-2246

5. Hines, J., Hungerford, H.R. \& Tomera, A. N. (1986/87). Analysis and synthesis of research on responsible environmental behavior: A metaanalysis. The Journal of Environmental Education, 18(2), 1-8.

6. Kaiser, F. G., Ranney, M., Hartig, T., \& Bowler, P. A. (1999). Ecological behavior, environmental attitude, and feelings of responsibility for the environment. European Psychologist, 4, 59-74

7. Kaplowitz, M., \& Levine, R. (2005). How environmental knowledge measures up at a big ten university. Environmental Education Research, 11(2), 143-160.

8. Kentucky Environmental Education Council. (2009). The 2009 Survey of Kentuckians' Environmental Knowledge, Attitudes and 
Behaviors. Retrieved from http://keec.ky.gov /publications/ surveys.htm

9. Ndaruzaniye, V. (2013). The Impact of Climate Change on Women in the African Societies: Gender policies. Available at http://www.gwiwater.org/sites/default/files/news/Impact\%20of\%20C limate\%20Change\%20on\%20Women\%20in\%20the\%20African\%20 Societies.pdf

10. Okukpon, L.A. (2008). Elements of Environmental Education. Ambik press Ltd, Nigeria

11. United Nations Environment Programme (2010). From Conflict to Peacebuilding: The Role of Natural Resources and the Environment. Available at http://postconflict.unep.ch/publications/pcdmb_policy_01.pdf 